\title{
Characterization Indigenous Phosphate Solubilizing of Bacteria (PSB) by in-Vitro from Dry Land of Northern Lombok
}

\author{
Lolita Endang Susilowati \\ Department of Soil Science Faculty of Agriculture \\ University of Mataram \\ Wahyu Astiko*) \\ Nurjannah
}

Study Program of Agroecotechnology Faculty of Agriculture University of Mataram,

Jln. Majapahit No. 62, Mataram, Lombok, Indonesia, 83125

*) Email for correspondence: astiko@unram.ac.id

\begin{abstract}
This study aimed to the characterization of PSB isolates related to the potential of each isolate in solubilizing phosphate qualitatively (Politkovskaya solid media) and quantitative (Politkovskaya liquid media). The research used the method descriptive experimental in the laboratory by using bacterial isolates that was identified from dryland namely Pseudomonas azotoformans, Acinetobacter baumannii, Bacillus paramycoides. This study consisted of two stages, namely I) solubilizing phosphate measurements qualitatively based on clear zones formed on the media and calculated by phosphate solubilizing index (SI) on days 2, 4, 6, 8, and 10. II) solubilizing phosphate measurements quantitatively with calculating absorbance values using a spectrophotometer, $\lambda=693$ $\mathrm{nm}$ on the media that has been inoculated bacteria and incubated at day 0, 2, 6, 4, 8. 10. Media was not inoculated with bacteria used as a control. Measuring $p H$ of the media on each day of incubation was done by using a pH meter. The results of the study showed that the characteristic of each isolate PSB to solubilize phosphate quantitatively and qualitatively differred. The qualitative of all three isolates produced SI values were: $P$. azotoformans of 1,777, B. paramycoides of 2,061, and A. baumannii of 2,124. The quantitative level of $P(\%)$ solubilize until the end of incubation were amounting of $0.07 \%, 0.09 \%$, and $0.44 \%$. Measurement of pH media in all three isolates tended to decrease during incubation. The pH of Isolates P. azotoformans from 6.24 to 4.87, A. baumannii from 6.24 to 4.32 and B. paramycoides from 6.24 to 4.3 .
\end{abstract}

Keywords: PSB, dry land, solubilizing phosphate

\section{I.Introduction}

The area of dry land in West Nusa Tenggara (NTB) reaches $84 \%$ of the total area of NTB. The area with potential of dry land in NTB, namely North Lombok, is only about 30\% used for the development of food crops, especially corn with low productivity (Suwardji et al., 2007). This is influenced by low soil fertility characterized by low content of organic matter, instable of aggregated soil, erosion sensitivity, and neutral to somewhat alkaline $\mathrm{pH}$ and relatively low main nutrient content (N, P, K) (Balitkabi, 2012). One of limited factor of nutrients in crop productivity is phosphorus $(\mathrm{P})$. The dissolved of $\mathrm{P}$ concentration in the soil is quite low due to $\mathrm{P}$ fixation which is high enough to be available slightly (Lestari et al., 2011). In general, the effort to provide the availability of phosphorus to plants by increasing the use of P-inorganic fertilizer. However, this has not been able to provide the availability of $\mathrm{P}$ effectively and efficiently because the roots of the plant are able to absorb $\mathrm{P}$ fertilizer only about 8-13\% of the amount of fertilizer given (Supardi, 1996). Therefore, the use of inorganic fertilizers is phosphate solubilizing of bacteria (PSB). Phosphate solvent bacteria are a group of soil bacteria that are capable of dissolving P fixed by soil minerals and liberating P-organic so that they can be converted into available forms for plants to absorb ( Susilowati and Syekhfani, 2014 ). Phosphate solubilizing bacteria will dissolve P-absorbed by removing organic acids, such as formic acid, acetic acid, propionate acid, lactic acid, and fumaric acid (Rakhma, 2011). 
The ability of BPF to dissolve phosphate varies depended on the genus of BPF found. Widiawati and Suliasih (2006) showed that there are two bacteria that have abilities quite high in phosphate dissolve the Pseudomonas sp. and Bacillus sp. Phosphate solvent bacterial populations are generally lower in dry climates compared to temperate regions. This is because the shape and amount of phosphate and organic matter contained in the soil differ among phosphate solvent microorganism. That is why; the effectiveness of each phosphate solvent microorganism is dissolve phosphate differently.

However, the characteristics of indigenous bacteria from North Lombok dry land have not been known as related to their potential in dissolving phosphate. Therefore, this study aimed to determine each characteristic of BPF isolates in dissolving phosphate in the media of solid Pickovskaya qualitatively and in the media of liquid Picovskaya quantitatively. The usefulness of this research is expected to be a reference related to the potential of BPF originating from North Lombok dry land in dissolving phosphate and as an effort to increase the efficiency of P. nutrient absorption.

\section{Materials And Methods}

This research used a descriptive method and was conducted in December 2017- February 2018 at the Laboratory of Microbiology, Physiology, and Biotechnology and Soil Chemistry, Faculty of Agriculture, Mataram University. The materials contained of Phosphate Solubilizing of Bacteria (PSB), I phosphate solvent bacterial solvents (BPF) with Code B (Pseudomonas azotoformans), C (Acinetobacter baumannii) and D (Bacillus Paramycoides) that were taken from the land of dry land which and was collected by Dr. Lolita Endang Susilowati and Mr. Zaenal Arifin.

\section{Characteristics of BPF in Phosphate dissolution}

Qualitative Phosphate Test. Tests were carried out by growing each of isolate BPF in a Petri dish containing of a solid Picovskaya media by using the spot inoculation method in Petri dish and was incubated for 10 days in the room Laboratory temperature. Observations were taken in days 2, 4, 6, 8 and 10 respectively. The dissolved phosphate index was measured when was marked by the appearance of the clear zone's formation (halo zone) with applying the following formula (Duangpaeng et al., 2013):

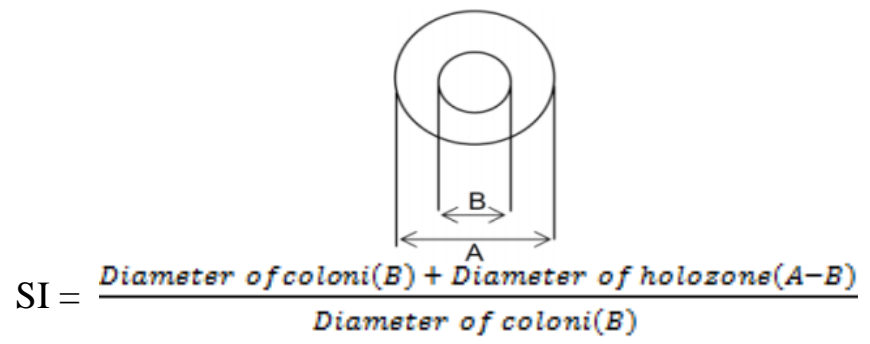

\section{Quantitative Dissolved Phosphate Test}

Making a Starter. Experiment was applied by taking one ounce of BPF isolate on a solid Picovskaya media then it was put it into $250 \mathrm{ml}$ Erlenmeyer containing of $100 \mathrm{~mL}$ liquid Picovskaya (ingredient composition: $5 \mathrm{~g}$ Ca 3 (PO 4 ) 2, 10 g glucose, $0.2 \mathrm{~g} \mathrm{NaCl}, 0,5 \mathrm{~g}$ (NH 4 ) $2 \mathrm{SO} 4,0.2 \mathrm{~g} \mathrm{KCl}, 0.1 \mathrm{~g} \mathrm{MgSO} .7 \mathrm{H} 2 \mathrm{O}, 0.005 \mathrm{~g} \mathrm{MnSO} 4$, $0.005 \mathrm{~g}$ FeSO $4,0.5 \mathrm{~g}$ yeast extract, $20 \mathrm{~g}$ agar , $1 \mathrm{~L}$ aquades ). The bacterial suspension was shaken using a shaker with a speed of $150 \mathrm{rpm}$ for 32 hours (Saragih, 2013) which was modified to 16 hours/day.

Calculation of Bacterial Population. The population of bacteria in the starter media was calculated by using the dilution glow method starting from $10^{-1}$ until $10^{-6}$. Each of dilution was pipetted into $0.1 \mathrm{ml}$ and put it on a Picovskaya media and was leveled by using Drigalski, then was incubated for $3 \times 24$ hours. The bacterial population is calculated using the Waluyo formula (2008) as follows:

Bacterial density $=$ number of colonies $\mathrm{x} \frac{1}{\text { dulation } \text { factor }}$

Solubilizing Phosphate Test. BPF suspension on the starter as much as $1 \mathrm{ml}$ with a bacterial population of 108 CFU / ml was inoculated into $100 \mathrm{ml}$ of sterile of Pikovskaya liquid in a $250 \mathrm{~mL}$ Erlenmeyer container and a media without bacterial inoculation as a control, then it was shakered with a speed of $150 \mathrm{rpm}$ for 16 hours/day. Observations were taken on days $0,2,4,6,8$ and 10 respectively by measuring the $\mathrm{pH}$ of the media and dissolved phosphate levels. Measurement of phosphate levels is determined by measuring the absorbance using a spectrophotometer, $\lambda=693 \mathrm{~nm}$. As a control, it was used an inoculated of BPF (Saraswati et al., 2007). 


\section{Results and Discussions}

\section{Characteristics of BPF in Phosphate Dissolving}

Acidity (pH) Media on Each Isolate

Measurement of $\mathrm{pH}$ in a liquid Picovskaya media showed that $\mathrm{pH}$ of the media of each isolate tended to decrease, as seen in Figure 1.

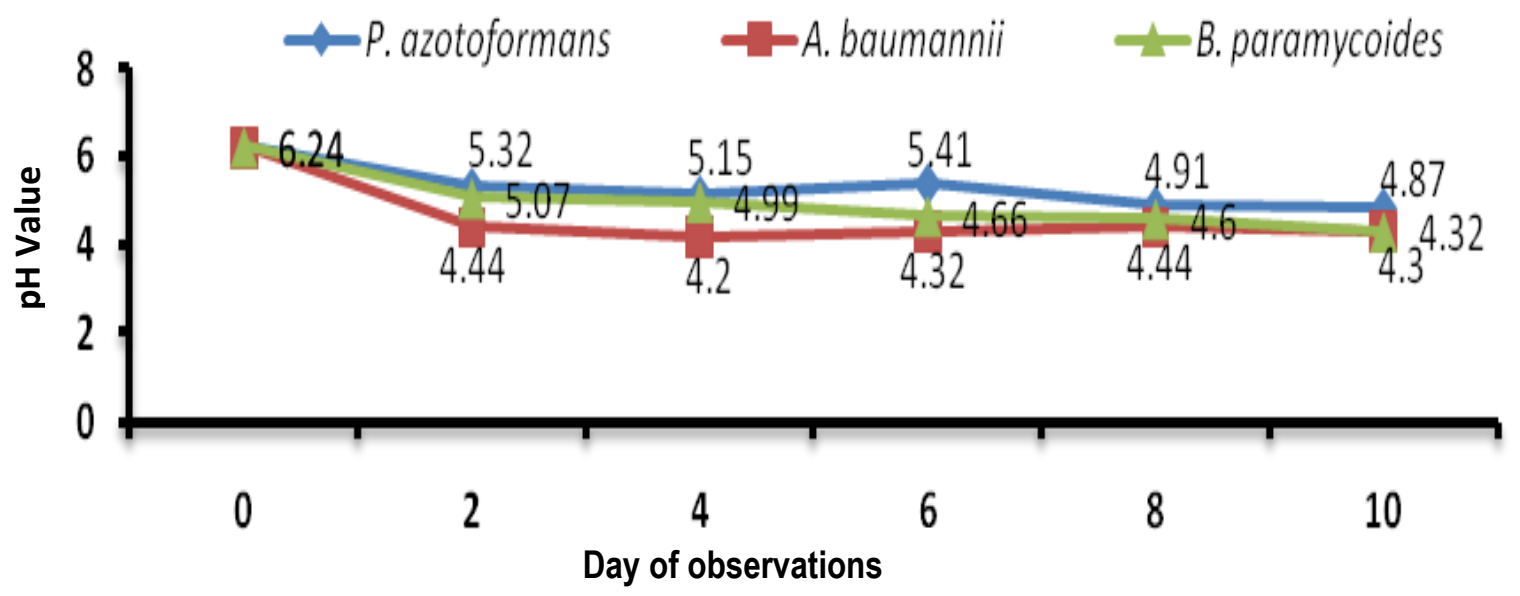

Figure 1. Changes in the $\mathrm{pH}$ value of the media in each isolate during incubation at day $0,2,4,6,8,10$

On the second day after the third incubation, isolates experienced a quite drastic decline. The $\mathrm{pH}$ values of $\mathrm{P}$. azotoformans and A. baumannii isolates fluctuated. They decreased from day 2 to 4 and then increased on day 6 and decreased again on days 8 and 10. The fluctuation of $\mathrm{pH}$ values in $P$. azotoformans and A. baumannii isolates during incubation supported the research of Sudadi et al. (2013) which showed a decrease level at incubation day 0,1 and 3 and an increase level at day 6 . The isolate $B$. paramycoides has declined continuously during incubation from day 2 to day 10. The study by Suliasih and Rahmat (2007) also showed the same pattern in isolate 11 for 6 days of incubation that on the $2^{\text {nd }}$ day the $\mathrm{pH}$ value decreased, then on the $3 \mathrm{rd}$ and 4 th days the $\mathrm{pH}$ values increased and on 6th day the $\mathrm{pH}$ value decreased again.

The ability of phosphate solvent bacteria is to produce organic acids which caused in decreasing the value of $\mathrm{pH}$ (Arcand and Schneider, 2006). The type and amount of organic acids produced by each isolate differ depending on the type of bacteria and the ability of the bacteria based on the genetics. This matter related to chemical reactions involving proton substitution reactions shown in equation (Goldstein, 1986 in Srividya et al., 2009): $\left(\mathrm{Ca}^{2+}\right) \mathrm{m}\left(\mathrm{PO}_{4}{ }^{3-}\right) \mathrm{n}+(\mathrm{HA})=\left(\mathrm{H}^{+}\right)\left(\mathrm{PO}_{4}{ }^{3-}\right)+\left(\mathrm{Ca}^{2+}\right)\left(\mathrm{A}^{-}\right)$

Based on these equations, HA is an organic acid produced by bacteria of varying types and different numbers of protons. The equation also shows the type and amount of organic acids produced by each bacteria affecting the number of protons $(\mathrm{H}+)$ production. The function of Proton $(\mathrm{H}+)$ is to bind phosphate anion, hydroxyl and carboxyl groups that will bond into phosphate cations. The occurance of Proton substitution reactions can be seen.

The decrease in the $\mathrm{pH}$ of the media that occurs can be caused by the process of bacterial respiration. A process of respiration and photosynthesis in by microorganisms form a chain-like carbonate compounds as an equation follows (Tneutron, 2017): $\quad \mathrm{CO}_{2}+\mathrm{H}_{2} \mathrm{O} \mathrm{H}_{2} \mathrm{CO}_{3} \mathrm{H}^{+}+\mathrm{HCO}_{3} 2 \mathrm{H}^{+}+\mathrm{CO}_{3}{ }^{2-}$

The more $\mathrm{CO} 2$ resulted from respiration, the reaction moved to the right and gradually released the $\mathrm{H}+$ ion which caused the $\mathrm{pH}$ to drop. The reverse reaction occurred at photosynthesis events which required a lot of $\mathrm{CO} 2$ ions, that caused the $\mathrm{pH}$ to increased.

\section{The Potential of Each Isolate in Phosphate Dissolving}

Qualitative phosphate dissolution was carried out by calculating the phosphate solubilizing index (SI) on solid Pickovskaya media. Qualitative measurement results are shown in Figure 2. 

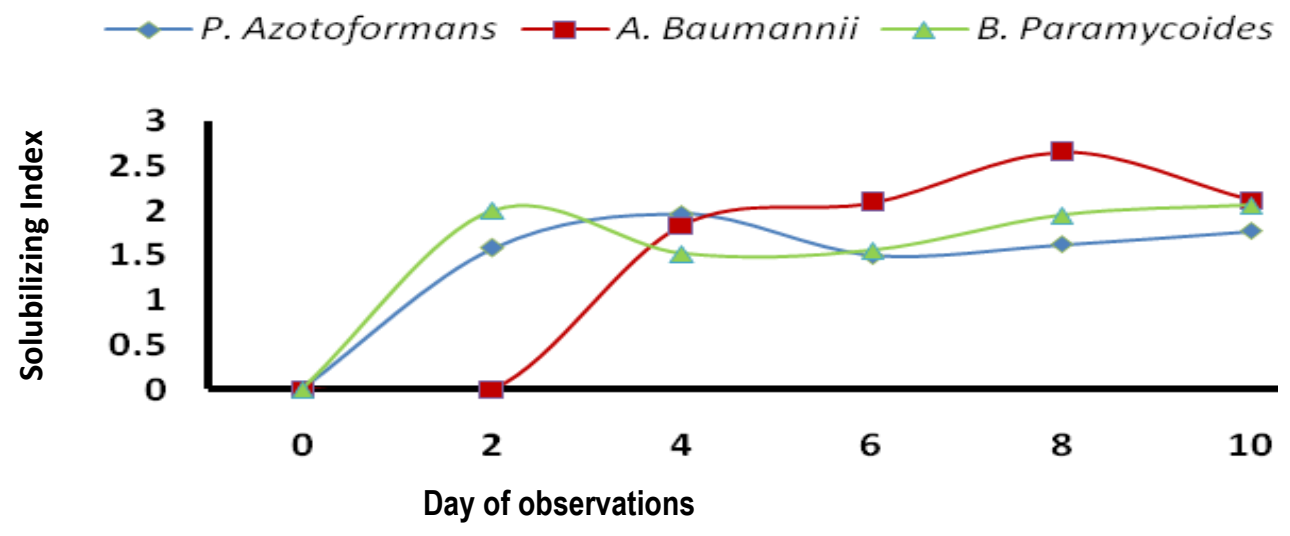

Figure 2 . Effect of isolation on phosphate solubilizing index (SI) during incubation day 0, 2, 4, 6, 8, 10.

Based on the SI values of each isolate during incubation, it was found that $P$. azotoformans isolates from day 0 to 4 increased, then it decreased on day 6 and it increased again on day 10. On the day 0 to 2, A. baumanii isolate was not able to dissolve phosphate as seen in the IPF with value of 0 . Then on the 4th day until the 8th day, it continued to increase and on the 10th day it decreased. On the day 0 to 2, B. Paramycoides isolate increased in the SI value, but it decreased on day 4 . On the day 6 to 10, the value of SI continued to increase. Changes in IPF values occurred in each isolate are based on their ability to form clear zones and growth of colonies in the media. The area of the clear zone showed the ability of bacteria to dissolve phosphate qualitatively, which showed the size or the capacity of the bacteria in dissolving phosphate (Rahayu et al., 2014). The quantitative potential of each isolate was determined by measuring absorbance using a spectrophotometer $\lambda=693 \mathrm{~nm}$ in liquid Pickovskaya media as shown in Figure 3.

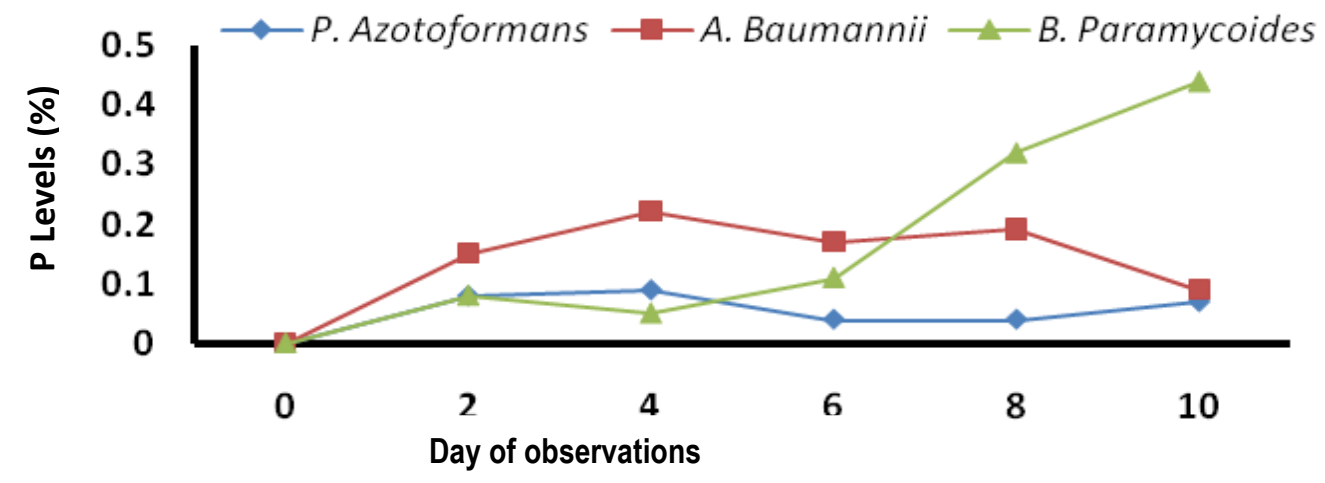

Figure 3 . Effect of types of isolates on $P$ levels (\%) during incubation days $0,2,4,6,8,10$.

The phosphate levels dissolved in each isolate during incubation on day 0 to 10 had different abilities. Widiawati (2007) stated that the ability of bacterial isolates in dissolving $\mathrm{P}$ depended on the metabolic process of the bacterial isolate itself. The metabolic process in each isolate caused different types and amounts of organic acids production. The lowest dissolved phosphate levels in $P$. azotoformans isolates occurred on days 6 and 8 were $0.04 \%$ and the highest levels occurred on the 6th day was $0.09 \%$. The lowest of A. baumannii isolate dissolved phosphate level occurred on the 10th day was $0.07 \%$ and the highest of that occurred on the 6th day was $0.22 \%$. The lowest of isolate B. soluble phosphate level occurred at day 4 was $0.05 \%$ and it increased in dissolved phosphate levels from day 6 to 10 so that the highest soluble phosphate level occurred on the 10th day was $0.44 \%$.

The same results were also shown in Suliasih and Rahmat (2007) that dissolved phosphate concentration in liquid media fluctuated during 6 days of observation and the highest was obtained on the first day observations for all observed isolates. Figure 4. also showed the ability of each isolate to produce dissolved phosphate levels from the highest to the lowest order occurred in B. paramycoides, A. baumannii, and P. azotoformans isolates respectively.

\section{Relationship Pattern of IPF with P (\%) Level of Each Isolate.}


The relationship pattern of the three isolates is relatively the same. When the pattern of IPF increased, then it was followed by an increased in the solubilize $\mathrm{P}$ level. This showed that the abilities and activities were carried out by the three isolates qualitatively and quantitatively tend to follow the same pattern (Figure 4 ).
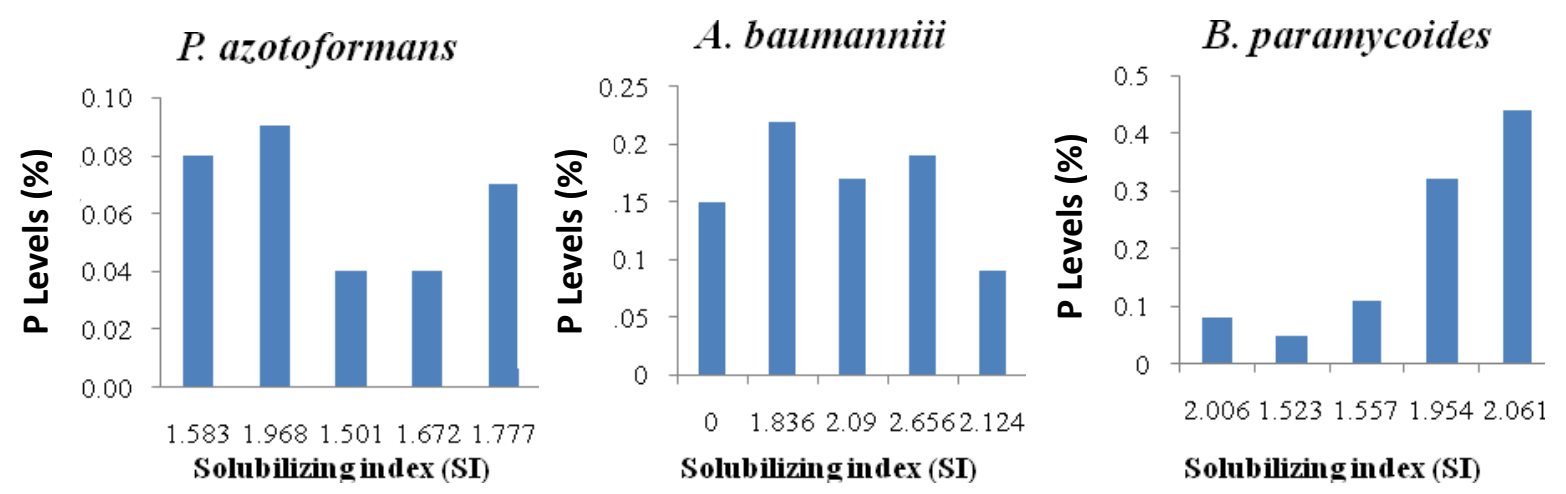

Figure 4 . Relationship pattern of IPF with P (\%) levels during incubation on days2, 4, 6, 8, 10 on $P$. azotoformans isolates, A. baumanni and B. paramycoides

P. azotoformans isolates with an SI value of 1,968 has dissolved P content of $0.09 \%, A$. baumannii isolates with a SI value of 1.836 has a dissolved P level of $0.22 \%$, and B. paramycoides with a SI value of 2.061 has a dissolved $\mathrm{P}$ was $0.44 \%$. These results were in accordance with the research of Susilowati and Syekhfani (2014) showed that the higher the IPF value, the higher the P content was also higher. Different patterns occurred in $A$. baumannii isolates showed that the IPF value increased, but not for the dissolved P level. On the 6th day, the SI value increased from 1,836 to 2,09 , but $\mathrm{P}$ levels decreased from $0,22 \%$ to $0,17 \%$. This was due to the characteristics of each different isolate in dissolving phosphate. Lestari et al. (2011) stated that the activity of each $\mathrm{P}$ solvent bacterial isolate differred from the one that grew on a solid medium from the one that grew in a liquid medium. The ability of bacteria in the liquid medium can be affected by aeration and the length of incubation time. According to Fankem et al. (2006), bacterial activities in dissolving P in solid and liquid media were not absolutely the same. The criteria for clear zones were not enough to determine the ability of bacteria to dissolve P.

\section{Conclusion}

Based on the results and discussions above, it can be concluded that: 1. Qualitatively all three isolates produced successive IPF values of P. azotoformans of 1.777, B. paramycoides of 2.061, and A. baumannii of 2.124, while quantitatively the level of $\mathrm{P}(\%)$ was dissolved at the end of incubation in a row of $0.07 \%, 0.09 \%$, and $0.44 \%$.

2. Measurement of $\mathrm{pH}$ of the media during incubation in all three isolates tended to decrease, namely in $P$. azotoformans isolates from $\mathrm{pH} \quad 6.24$ to 4.87, A. baumannii isolates from $\mathrm{pH} \quad 6.24$ to 4.32 and $B$. paramycoides isolates from $\mathrm{pH} \mathrm{6,24}$ to 4.3.

\section{Acknowledgements}

The authors thanks to the Study Program of Agroecotechnology Department of Agriculture, Mataram University for the opportunity to conduct research with its laboratory facilities

\section{References}

Arcand IM, Schneider KD 2006. Plant and Microbial Based Mechanisms To Improve The Agronomic Effectiveness Of Phosphate Rock. A Review of the Annals of the Brazilian Academy of Sciences. 78 (4): 791-807.

Various Peanut and Tuber Crops Research Institute (Balitkabi). 2012. NTB Dry Land Potential for Soybean Seed Production. Http: // Balitkabi. $R$ \& D. Agriculture. Go. Id /? P = 1816 [September 20, 2017].

Duangpaenga A., Phetcharata P., Chanthaphoa S., Okudab N. 2013. Screening of endophyte bacteria for phosphate solubilization from organic rice . Proceeding - Science and Engineering (2013): 61-66. 
Fankem H., Nwaga D., Deubel A., Dieng L., Merbach W., Etoa FX 2006. Occurence And Functioning Solubilizing Microorganisms From Oil Palm Tree (Elaeis guineensis) Rhizospher in Comeroon.African Journal of Biotechnology. 5 (24); 2450-2460.

Lestari Wahyu, Linda Tetty M., Martina A. 2011. Ability of Isolate Phosphate Solubilizing Bacteria from Sei Garo In Provision of Dissolved Phosphate and Its Absorption in Soybean Plants. Biospecies, V olume 4 No. 2, July (2011) 1-5.

Rahayu F., Mastur, Santoso B. 2014. Potential of several Bacterial Isolates from Cane Phosphate Solvents in Java Island based on Phosphatase Enzyme Activity. Tobacco Crops, Industrial Fiber and OilBule . 6 (1): 2331.

Rakhma Y. 2011. Characterization of the Capability of Dissolving Phosphate Solvent Bacteria Phosphate Origin of Tithonia Diversifolia in the Media of Soil Extract . Faculty of Agriculture Andalas University. Padang.

Saragih BA 2013. Screening of Vinasse Adaptif Phosphate Solvent Bacteria From the Jatirotok Sugar Cane Land in Lumajang Regency, East Java. [ Unpublished thesis] . University of Jember.

Srivdya, Soumy S., Pooja K. 2009. Influence of Environmental Factors and Salinity on Phosphate Solubilization by Newly Isolated Aspergillus niger F7 From Agricultur Soil. African Journal of Biotechnology. 8 (9): 1864-1870.

Sudadi, Widijanto H., Putri LHE 2013. Isolation of the original microbes of andisol dieng soil and its potential study as an inoculant of phosphate solvent biofertilizer. Journal of Soil Science and Agroclimatology Vol. 10 (2).

Suliasih and Rahmat. 2007. Activity of Phosphotase and Calcium Phosphate Dissolution by Some Phosphate Solubilizing Bacteria. Journal of Biodiversity Vol 8 (1): 23-26.

Supardi G. 1996. Exploring the Effects of Synergy Towards Agricultural Responsibility. HITI News. 4 (12): 1013 .

SusilowatiLE, Syekhfani. 2014. Characterization of Phosphate Solubilizing Bacteria Isolated From $\mathrm{Pb}$ Contaminated Soils And Their Potential For Dissolving Tricalcium Phosphate . Journal of Degraded and Mining Lands Management Vol 1 (2): 57-62

Suwardji, Suardiari G., Happi A. 2007. Increasing the efficiency of irrigation water from groundwater sources on dry land of northern Lombok watershed using sprinkler big gun irrigation technology.Proceedings of the December 5-7 national congress of Yogyakarta, Yogyakarta.

Tneutron. 2017. Factors that determine the $\mathrm{pH}$ of water. https: // www. tneutron.net/ blog / factor-whichdetermine-value-ph-air /. [March 20 2018].

Widiawati S. and Suliasih. 2006. Potential of Phosphate Solvent Bacteria Augmentation (BPF) as Growth Caysin (Brasica Caventis Oed.) In Marginal Land. Journal of Biodervisitas Vol. 7 (1).

Widiawati E. 2007. Microbial Inoculum Formulation: Arbuscular Mycorrhiza, BPF and Rhizobium from Former Coal Mine for Ex-Bent Acacia crasicarpa Cunn Seeds. Journal of Biodiversity 8(3): 238-241 